\title{
Correction to: Structural Health Monitoring Damage Detection Systems for Aerospace
}

\author{
Markus G. R. Sause (D) and Elena Jasiūnienė (D)
}

\section{Correction to:}

M. G. R. Sause, E. Jasiūnienè (eds.), Structural Health Monitoring

Damage Detection Systems for Aerospace, Springer Aerospace Technology, https://doi.org/10.1007/978-3-030-72192-3

The original version of this book was inadvertently published with outdated acknowledgement text in the front matter and without including the funder's logo in the front cover. Now, both these corrections have been updated in the front matter and front cover. 